NBER WORKING PAPER SERIES

ON

HISTORICAL FACTORS IN LONG RUN GROWTH

\author{
MASS MIGRATION, COMMODITY MARKET \\ INTEGRATION AND REAL WAGE \\ CONVERGENCE: THE LATE NINETEENTH \\ CENTURY ATLANTIC ECONOMY
}

Jeffrey G. Williamson

Kevin O'Rourke

Timothy J. Hatton

Historical Working Paper No. 48

\author{
NATIONAL BUREAU OF ECONOMIC RESEARCH \\ 1050 Massachusetts Avenue \\ Cambridge, MA 02138 \\ June 1993
}

Preliminary draft. Comments welcome but please do not quote. Paper to be presented to the conference on "Migration and International Labor Market Integration in the 19th and 20th Centuries," Villa Serbelloni, Bellagio, Italy (June 14-18, 1993). This paper is part of NBER's research programs in Development of the American Economy and Growth. Any opinions expressed are those of the authors and not those of the National Bureau of Economic Research. 
NBER Historical Paper \#48

June 1993

\title{
MASS MIGRATION, COMMODITY MARKET \\ INTEGRATION AND REAL WAGE \\ CONVERGENCE: THE LATE NINETEENTH \\ CENTURY ATLANTIC ECONOMY
}

\begin{abstract}
As part of a process that has been at work since 1850 , real wages among the current OECD countries converged during the late 19 th century. The convergence was pronounced as that which we have seen in the post World War II period. This paper uses computable general equilibrium models to isolate the sources of that economic convergence by assessing the relative performance of the two most important economies in the Old World and the New -- Britain and the USA. It turns out that between 1870 and 1910 , the convergence forces that mattered were those that generated by commodity price convergence, stresses by Eli Heckscher and Bertil Ohlin, and mass migration, stressed by Knut Wicksell. It turns out that offsetting forces were contributing to late 19 th century divergence, a finding consistent with economic historians' traditional attention to Britain's alleged failure and America's spectacular rise to industrial supremacy. The convergence forces, however, dominated for most of the period.
\end{abstract}

Jeffrey G. Williamson

Department of Economics

Harvard University

Cambridge, MA

FAX (617) 495-7730

TEL (617) 495-2438

and NBER

Timothy J. Hatton

University of Essex

Colchester CO4 3SQ

ENGLAND
Kevin O'Rourke

University College Belfield

Dublin 4

IRELAND

FAX 353-1-283-0068

TEL 353-1-706-8509 


\section{INTRODUCTION}

Most economists know about the post World War II economic convergence among members of the OECD industrialized club. They are less likely to know that convergence has been a fact of economic life since the 1850 s (Baumol et a1., 1989; DeLong, 1988; Williamson, 1992). The experience has been manifested by three regimes: the late nineteenth century convergence up to 1913 ; a cessation of convergence between the start of World War I and the conclusion of World War II; and the resumption of convergence since. The late nineteenth century convergence among members of the current OECD club is especially interesting for three reasons: it was as dramatic as the more recent experience since 1950; it was manifested primarily by the erosion of gaps between the New World and the 0ld, rather than by an erosion of gaps within either region; and it took place in an environment of relative free factor and commodity flows.

What role did factor and commodity flows play in contributing to the economic convergence in the late nineteenth century? If the answer is "big", can we conclude that the cessation of convergence 1913-1950 and its resumption since can also be largely explained by those open economy forces?

This paper uses computable general equilibrium models to isolate the sources of the late nineteenth century economic convergence by assessing the relative performance of the two most important economies in the 01d World and the New World -- Britain and the USA. We attack the problem by identifying that portion of the factor price convergence which was set in motion by commodity trade and factor flows, thus emerging with a residual which might be 
assigned to those forces stressed by Alexander Gerschenkron (1952), Moses Abramovitz (1986) and the new growth theory. We find that the latter did not contribute to factor price convergence. The convergence forces that mattered were commodity market integration, stressed by Eli Heckscher and Bertil Ohlin, and mass migration, stressed by Knut Wicksell. It turns out that offsetting forces were contributing to late nineteenth century divergence, a finding consistent with economic history's traditional attention to Britain's alleged industrial failure (McCloskey, 1970) and America's spectacular rise to industrial supremacy (Wright, 1990; Nelson and Wright, 1992).

The paper begins by assessing the impact of the mass migrations maintaining what might be called Knut Wicksell's (1882) comparative static assumptions. It then asks which of Wicksell's assumptions are most likely to have been violated, including the issue of whether capital chased after labor, an endogenous accumulation response which might have muted the net impact of the mass migrations on capital-shallowing in the New World and capitaldeepening in the $01 \mathrm{~d}$. The paper then estimates the impact of Heckscher/Ohlin trade-related effects, both with and without endogenous migration responses. We conclude with an overall assessment of the sources of the late nineteenth century Anglo-American convergence. The conclusion includes an estimate of residual forces which persist after having taken account of factor flows and commodity trade, as well as a discussion as to whether these findings are likely to hold more generally for the full OECD sample.

\section{THE IMPACT OF MIGRATION: MAINTAINING WICKSELL'S CLASSICAL ASSUMPTIONS}

Is international migration a good or a bad thing? The debate is at least 
as old as the industrial revolution in Europe, which sent so many emigrants to the New World in the nineteenth century. As Michael Greenwood and John McDowel1 (1986, pp. 1745-7) point out, the debate also has a long history in the United States, the New World country which absorbed the majority of the emigrants leaving Europe. It reached a crescendo in 1911 after the Immigration Commission had pondered the problem for five years. The Commission concluded it was a bad thing, contributing to poor working conditions, and those findings helped create the quota legislation implemented in the 1920s. But how did the Imnigration Commission reach its conclusion? For that matter, how do modern economists reach their conclusions regarding today's migrations?

Like the more general population debate (Kelley, 1988), historical correlations between migration and real wages are unlikely to offer any clear answer to the question: Does emigration (immigration) raise (lower) real wages? After all, immigrants were always pulled into the United States when the economy was booming for other reasons -- e.g., the 1830s, the late $1840 \mathrm{~s}$ and $1850 \mathrm{~s}$, the late $1860 \mathrm{~s}$ and early 1870s, the 1880s and the 1900s. They avoided the United States when the economy was undergoing macroeconomic bust and slowdown - e.g., most of the 1840s, most of the $1870 \mathrm{~s}$, and most of the 1890s. Historical correlations like these tell us about immigrant response to changing labor demand conditions in the United States, not about the absorption of the immigrants along some stable labor demand curve.

The same can be said for the intertemporal cross-section in Figure 1 where real wages and population growth are plotted for the century 1870-1988. The evidence presented there surely does not imply that faster immigrantaugmented population growth raised real wages, but rather that scarce labor encouraged a supply response. Part of that supply response took the form of 
high fertility and low mortality, and part of it took the form of migration. Thus, the major emigrating labor abundant countries tend to lie to the left in the figure while the major immigrating labor scarce countries tend to lie to the right. Furthermore, a good share of the implied population redistribution was attributable to migration, especially in the late nineteenth century. Up to 1913, immigration accounted for 50 percent of Argentina's, and 30 percent of Australia's population increase (Taylor, 1992, Table 1.1). Between 1870 and 1910, immigration accounted for 28 percent of population increase in the United States (Easterlin, 1968, p. 189). Between 1871 and 1890, emigration reduced Swedish population increase by 44 percent (Karlstrom, 1985, pp. 155, 181); between 1870 and 1910, it reduced British population increase by 21 percent (Mitchell and Deane, 1962, pp. 9-10); while, based on emigration rates, even bigger shares must have characterized Ireland, Italy, and Norway. Furthermore, and as we shall see, since the mass migrations were selective of young adult males with high labor participation rates, the impact was even larger on the sending and receiving labor force.

So, by how much did these mass migrations cause real wages in the laborabundant old World to catch up with real wages in the labor-scarce New World? In the early 1880s, Knut Wicksell, then a relatively young economic theorist and a neo-Malthusian, asserted that emigration would solve the pauper problem which blighted labor-abundant and land-scarce Swedish agriculture (Wicksell, 1882; cited in Karlstrom, 1985, p. 1). In spite of the intensity of the debate on the impact of late nineteenth century mass migrations that ensued over the century since Wicksell wrote, no test of his assertion has been offered.

Furthermore, what literature there is typically asks what the impact on the receiving (or less frequently, the sending) region was alone, rather than 
asking questions about convergence between them. The difference matters. After all, if real wages were growing at 2 percent per annum in the labor-scarce country and 3 percent in the labor-abundant country, and if the 1 percent difference were attributable entirely to external migration, we might correctly conclude that migration accounted for only one-quarter of real wage growth in the labor scarce immigrating country (say, half of the 1 percent, 0.5 percent, divided by 2 percent) and for only one-sixth in the labor abundant emigrating country ( 0.5 percent divided by 3 percent), while incorrectly concluding that migration didn't contribute much to the (significant) convergence when in fact it accounted for all of it. The moral of the story is that we must explore the two regions simultaneously.

The standard way of presenting the problem on the blackboard is illustrated in Figure 2. New World wages and labor's marginal product are on the lefthand side and 01d World wages and labor's marginal product are on the righthand side. The world labor supply is measured along the horizontal axis. An equilibrium distribution of labor, of course, occurs at the intersection of the two derived labor demand schedules ( $O$ and $N$ ). Instead, we start at $1^{1}$ where labor is scarce in the New World, and thus where the wage gap between the two regions is very large, $w_{n}{ }^{1}-w_{0}{ }^{1}$. If ${ }^{n}$ mass" migrations redistribute labor towards the New World, say to $1^{2}$, the wage gap collapses to $w_{n}{ }^{2}-w_{o}{ }^{2}$, and all the observed convergence would be attributable to migration. However, exactly the same convergence could have been achieved by a relative shift in 0 to $0^{\prime}$, an event driven perhaps by relative price shocks favoring labor in the 01d World or by faster accummulation and technological "catching up" there. Figure 2 is certainly an elegant statement of the question, but how do we implement the answer empirically? 
The way to proceed, of course, is to develop a model in which the Iong run impact of the mass migrations can be assessed. We favor the application of computable general equilibrium (CGE) models, but we are well aware of the debatable assumptions which may drive the results. That the models focus on long run supply side forces seems appropriate, but, following Wicksell, we also assume the absence of scale economies, accumulation responses, and influences on the rate of technological change. It seems to us sensible to ask first whether those migrations would have mattered to the evolution of international wage gaps if standard classical, comparative static assumptions were approximated by reality. With first order impacts estimated, we can then explore whether the relaxation of Wicksell's classical assumptions are likely to overturn our interpretation of history.

While an historical assessment of the impact of the late nineteenth century mass migrations is our ultimate goal, we begin by reporting in Table 1 the few estimates on sending and receiving regions that have been offered recently. All of them generate estimates by imposing a no-migration counterfactual on some CGE model of the sending or receiving region. The two cases of late nineteenth century mass migration both yield far bigger effects than that for the Irish immigrations into early nineteenth century Britain: the emigrations from Sweden in the 1870 s and 1880s (most of which went to the US) served to raise real wages there by 4.9 percent per decade; the immigrations into the United States from 1870 to 1910 (some of whom were Swedes) served to lower real wages there by 2.5 percent per decade. Swedish real wages were only 24 percent of United States real wages in 1870 , but they had climbed to 58 percent of the United States by 1913 , so that the wage gap declined by 34 percentage points (Williamson, 1992). According to the rough 
estimates in Table 1, mass migrations served to erode the Swedish-American wage gap by 9 percentage points, accounting for about a quarter of the impressive erosion in the Swedish-American wage gap between 1870 and 1913. Had overseas migration been the only convergence force at work, and had it continued at the same (enormous) rate, it still would have taken far more than a century to eliminate the 1870 real wage gap between labor-scarce America and labor-abundant Sweden. Of course, it would not have continued at the same rate: as the wage gap eroded the emigration rate would have declined (Hatton and Williamson, 1992b), thus extending the point of parity out even further in time.

This tentative empirical application of classical thinking suggests that mass migrations made a significant contribution to real wage convergence between Sweden and America in the late nineteenth century, much like Wicksell predicted. However, it also suggests that there were other important convergence forces at work.

The argument can be strengthened by its application to another pair of countries, the United States and Britain. A recent paper by one of the present authors (Williamson, 1992) constructed a purchasing-power-parity adjusted urban unskilled real wage data base for 15 countries over the very long run. The 1870-1913 evidence is summarized in Figure 3 by a coefficient of variation, $\mathrm{C}(15)$, and it documents considerable convergence. Furthermore, the late nineteenth century real wage convergence is similar in magnitude to the better-known convergence after World War II (and a bit bigger than the convergence implied by per capita income data: Williamson, 1992). Perhaps most interesting, however, is the finding that most of the late nineteenth century real wage convergence can be attributed to an erosion in the real wage gap 
between the old and New World (Dno in Figure 3), and not to any significant convergence within the old World (Do) or within the New (Dn). Around 1870, real wages in the labor scarce New World (Argentina, Australia, Canada and the USA) were much higher than in the labor abundant old World (Ireland, Great Britain; Denmark, Norway, Sweden; Germany; Belgium, Netherlands, France; Italy and Spain), 136 percent higher. By 1895, real wages in the New World were "only" 100 percent higher, and in 1913 they were "only" about 87 percent higher. In short, the real wage gap between old World and New fell 36 percentage points over the twenty-five years up to 1895, and by 49 percentage points over the forty-three years up to 1913. The old World caught up quite a bit with the New. While the magnitudes were less dramatic, what was true of old and New World was also true of two of the most important members in each: in 1870 , real wages in the USA were 66.7 percent higher than in Britain while in 1890 they were "only" 49.5 percent higher, in 189544 percent higher, in 191061.9 percent higher, and in 191354 percent higher. Thus, the AngloAmerican real wage gap fell by 17.2 percentage points over the twenty years up to 1890 , by 4.8 percentage points over the forty years up to 1910 , and by 13 percentage points over the forty-three years up to 1913. Britain caught up a bit with the United States, a surprising finding given all that has been said about Britain losing her leadership to America. It must be said, however, that all of the British catch up took place prior to 1895, not afterwards, when American industrial ascendancy was most dramatic (e.g., see Wright, 1990). We shall have more to say about these two regimes below.

We now ask: How much of the Anglo-American real wage convergence after 1870 can be explained by total British net emigration and total American net immigration? The open, multi-sector British and American CGEs are described in 
Appendix 1, but they are in the classical, comparative static tradition: in the counterfactual experiment, land, capital and technologies are, at least initially, kept fixed; only labor is allowed to vary in the no-Americanimmigration and no-British-emigration counterfactuals. The US labor force would have been about 13 percent smaller in 1890 without the net immigrations 1870-1890, and about 27 percent smaller in 1910 without the net immigrations 1870-1910. The British labor force would have been about 11 percent larger in 1890 without the net emigrations $1870-1890$, and about 16 percent larger in 1910 without the net emigrations 1870-1910. (Appendix 2. All of these calculations include the influence of migrant children born after the move. If the children of the migrants are ignored, the 1910 US labor force would have been about 18 percent smaller in the absence of immigration, not 27 percent; and the 1910 British labor force would have been 10 percent larger in the absence of emigrants, not 11 percent.)

What would have been the impact on these two economies had these migrations not taken place? The results are presented in Panel A of Table 2, and they are very big. In 1910, real wages would have been 34 percent higher in the US and 12.2 percent lower in Britain. American real wage rates were actually about 61.9 percent higher than British in 1910; without the late nineteenth century migrations they would have been about 147 percent higher. The Anglo-American real wage gap fell between 1870 and 1910 ; without the late nineteenth century migrations it would have more than doubled!

There would have been no Anglo-American convergence without international migration. Wicksell's classical assumptions suggest that overseas migrations made a central contribution to factor price convergence between old World and New in the late nineteenth century. 


\section{RELAXING WICKSELL'S GLASSICAL ASSUMPTIONS}

Optimists in the migration debate would, no doubt, argue that the classical assumptions made thus far overstate the impact of the late nineteenth century mass migrations. What follows is a list of the ones which, we suspect, the optimists would stress.

First, we have assumed that labor is homogeneous: natives and migrants are taken to be unskilled, and they compete for the same jobs. In contrast, economists assessing postwar American experience with immigration tend to view migrants and natives more as complements (see the summaries in Simon, 1989, and Borjas, 1990). While two of us have offered argument elsewhere as to why the modern complementarity position should be viewed with skepticism (Hatton and Williamson, 1992a), and while more recent research on post-World War II American experience confirms that skepticism (Borjas and Freeman, 1992), there is reason in any case to think that conditions were quite different a century ago. After all, skilled labor was a much smaller share of the labor force in both sending and receiving regions in the late nineteenth century than it is now; skills (post-literacy formal education in particular) were much less important to 1890 technologies than they are to 1990 technologies. Furthermore, human capital gaps between migrants and native born were much smaller than they are today (especially in the 1980s: Bor jas, 1991), and there is very little evidence to suggest that foreign labor entered segmented occupations or lacked mobility. Substitutability is far more likely to have characterized labor markets in the late nineteenth century than complementarity: new emigrants competed directly with the native-born and old emigrants at the bottom end of the labor market. Claudia Goldin (1993) has 
recently offered some American evidence from the turn of the century which is consistent with our view.

Second, the optimistic view argues that migrants contribute to a demand boom. This view was certainly dominant in the historical literature of the 1950 s and 1960s when Keynesian thinking was in vogue (Thomas, 1954; Easterlin, 1968; Abramovitz, 1961, 1968). A modern version has recently been offered to account for the view that immigrants never robbed jobs from Australians in the past (Pope and Withers, 1990). While this view might be credible in the short run, it is very unlikely, in our view, to be credible for periods spanning as much as forty years.

Third, the optimistic view stresses increasing returns, and it is now firmly embedded in the new growth theory (Romer, 1986). In spite of all that has been said about increasing returns, however, there has been no persuasive evidence offered to confirm it for the nineteenth century.

Fourth, there is what American economic historians call the Walker Effect (Neal and Uselding, 1972). The argument is that had American labor been even more scarce in the absence of the immigrants, native fertility rates would have risen to take up the slack. Since real wage trends explain so little of New World experience with fertility changes (Lindert, 1978), it seems unlikely that a native fertility response would have mattered much in muting the impact of the mass migrations. This is not to say that old World demographic forces had no influence on emigration. Indeed, Hatton and Williamson (1992b) have shown that demographic booms and busts had a powerful effect on European mass emigrations. Rather, we are saying that real wage changes had only a modest impact on fertility.

Finally, there are the more conventional accumulation and comparative 
advantage responses to consider. Might there have been immigrant-induced long run supply-side responses which simultaneously shifted the labor demand curve to the right just when immigrant-induced rightward shifts in labor supply were taking place? We find these arguments more compelling, and the sections following will explore them at length.

\section{DID CAPITAL CHASE AFTER IABOR AND DID IT MATTER?}

In the simple two-factor model, labor should migrate from the low-wage to the high-wage country, and capital should migrate from the high-wage (low returns) to the low-wage (high-returns) country. The better integrated are world capital markets, the faster the real wage convergence. And if world capital markets become better integrated over time, the rate of convergence should accelerate, and if world factor markets break down, convergence should slow down.

Crude correlations would appear to be consistent with these predictions. After all, there was dramatic real wage convergence during the second half of the nineteenth century, trends which appear to track evolving world capital market integration. The size of the international capital flows was very large, with Britain at the center (Edelstein, 1982). Furthermore, there is evidence that world capital markets were at least as well integrated around 1890 as they were around 1980 (Zevin, 1992). In addition, real wage convergence ceased from the start of World War I to the end of World War II, three decades during which global capital markets collapsed.

Crude correlations may be misleading, however, since the two-factor model is an inadequate characterization of late nineteenth century history. What 
really distinguished the old World from the New was natural resource endowment, and that fact motivates the concept of New World "dual scarcity" (Temin, 1966). Resources were abundant there, while both capital and labor were scarce. And there is plenty of evidence that capital and labor moved together as a consequence: that is, labor emigrated from capital exporting old World countries (like Britain, Germany and France) and labor immigrated into capital importing New World countries (like Argentina, Australia, Canada and the USA).

If capital and labor moved together, can it still be said that the overseas mass migrations really contributed to Anglo-America real wage convergence? We need to know whether the international flow of labor dominated the flow of capital. If it did, then it served to lower the capitallabor ratio in America compared with Britain, thus contributing to wage convergence. Given the impressive size of the literature on late nineteenth century capital flows and mass migrations, one would have thought it would be a simple matter to find evidence assessing the net impact of both flows on capital-labor ratios in the sending old World and the receiving New World. We are unaware of any such estimates, however. Capital-deepening over time can be written as $d(K / L)=(K / L) *([d K D / K-d L D / L]+[N F I / K-M I G / L]\}$. The first term on the right-hand side of this expression refers to domestic and the second to foreign sources of capital-deepening (NFI is equal to the current account balance and MIG is equal to net migration). It is the second term which interests us, and Table 3 offers some evidence for the labor and capital importing United States and labor and capital exporting Britain.

Labor migration clearly dominated capital migration in the United States between 1870 and 1910: while foreign capital imports served on average to 
raise the rate of accumulation by a trivial amount over the four decades as a whole, 0.03 percent per annum, foreign immigration tended to raise the rate of labor force growth by a lot, 0.82 percent per annum. In combination, international factor flows served to lower the rate of capital-deepening in the US by 0.79 percentage points per annum (col. 3, 1870-1910): external factor flows into the United States cut the rate of capital-deepening by more than a quarter $(-.79 /[2.02+.79]=-0.28)$.

Britain, however, appears to offer a different story. Table 3 suggests that British capital moved with labor in such massive amounts that international factor migration must have inhibited convergence: emigration served to lower the rate of labor force growth in Britain by about 0.38 per annum between 1870 and 1910 , but capital exports served to lower the rate of accumulation by far more, 2.15 percent per annum. External factor flows did not raise the rate of capital-deepening in Britain, but rather lowered it by 1.77 percent per annum (col. 3, 1870-1910): according to this calculation, British export of capital and labor served to cut the rate of capitaldeepening by almost three-quarters $(-1.77 /[0.68+1.77])=-0.72)$. Thus, British factor exports could not have contributed to Anglo-American real wage convergence in the late nineteenth century.

Yet, while capital was exiting Britain faster than was labor, how much of it was actually chasing after labor? The answer is illusive, but we can take a crude cut at the problem by identifying the direction of the flows. Almost all British emigrants went to North America, Australia and New Zealand, but only 45 percent of her capital exports went to the same regions (Simon, 1967). Thus, the "chasing" component of British capital exports cannot have reduced the rate of capital accumulation by more than about 1 percentage point per 
annum $(0.45 x-2.15=-0.97)$, thus reducing the measured impact on capitaldeepening to 0.59 percent per annum. Even then, we do not know how much of the British capital exports to North America, Australia and New Zealand was actually chasing after that labor, and how much of it was responding to third factors.

Although the phrase "capital chased after labor" has been frequently used to describe overseas settlement in the late nineteenth century, third factors surely helped pull both of them abroad. To estimate the impact of labor migration on real wage convergence, we need to identify that share of British capital flowing to the New World which was chasing after labor. We cannot. But we can place an upper bound on the estimate by exploring a second question: What happens in the no-migration counterfactual reported in Table 2 when capital is allowed to chase after labor, that is, when world capital markets are treated as perfectly integrated? Panel B supplies the answer. But before we look at Panel B, note in Panel A the impact on the return to capital in the no-migration counterfactual when international capital is assumed immobile. The capital-labor ratio rises (falls) in the United States (Great Britain) so the return to capital falls (rises). Thus, if capital is now allowed to be perfectly mobile, some of it will retreat from America and stay home in Britain, muting the impact of migration's effects. Now look at Panel B: in this no-migration counterfactual, 1910 real wages would have been 9.2 percent higher in the US and 6.6 percent lower in Britain. American real wages were actually 61.9 percent higher than in Britain in 1910; without the late nineteenth century migrations, and without that part of the capital flows that 
chased after the migrants ${ }^{1}$, the American real wage advantage would have been even higher, 89.3 percent; furthermore, there would have been no Anglo-

American real wage convergence in the late nineteenth century, since the 1870 American real wage advantage of 66.7 percent would have risen to 89.3 percent by the end of the period.

The moral of the story is that international migration contributed to Anglo-American real wage convergence even if we allow for perfect capital market integration and thus for an elastic accumulation response. The central reason why these results are so robust is, of course, the presence of an important third factor in the late nineteenth century, natural resources.

\section{WHAT ABOUT COMMODITY MARKETS AND THE FACTOR-PRICE-EQUALIZATION THEOREM?}

Ever since Eli Heckscher and Bertil Ohlin made their pioneering contributions shortly after World War I, trade theorists have understood that real wage convergence can take place in the absence of international migrations: commodity trade can, at least in theory, serve as substitute for labor migration. What role did the integration of international commodity markets play in forging a global labor market and contributing to real wage convergence? In spite of the importance this issue has played in the trade literature, until recently (0'Rourke and Williamson, 1992; 0'Rourke, Taylor

${ }^{1}$ The no-migration simulations in Panel B of Table 2 assume a perfectly elastic external capital supply, an extreme assumption of course. But it does offer an upper bound on the capital that might have chased after labor in the late nineteenth century. The simulations imply the following magnitudes: had capital not chased after the immigrants entering the USA between 1870 and 1910 , the rate of accumulation in the USA would have been lower by 0.70 percent per annum; and had capital not chased after the emigrants leaving Britain between 1870 and 1910, the rate of accumulation in Britain would have been higher by 0.25 percent per annum. 
and Williamson, 1993) no one has explored its empirical relevance for the late nineteenth century, the period that motivated Heckscher and Ohlin in the first place..$^{2}$

The factor-price-equalization (FPE) theorem has been a durable tool in trade theory for seventy years. The Heckscher-Ohlin paradigm has it that countries tend to export commodities which use intensively the factors in which they are well endowed while they tend to import commodities which use intensively the factors in which they are poorly endowed. Furthermore, it can be shown under (very) restrictive assumptions that a move from no trade to free trade can in fact equalize factor prices where wide differences existed before. Consider this relevant historical example: Let falling transport costs and declining tariff barriers tend to equalize prices of traded commodities. Countries will now export more of the goods which exploit their favorable factor endowment. The demand for the abundant and cheap factor booms while that for the scarce and expensive factor slumps. Thus, commodity price convergence tends to produce factor price convergence, although theory is ambiguous about how much.

When Heckscher was writing in 1919 and Ohlin in 1924, they were motivated by the commodity price convergence which they thought had taken place between the old World and the New in the late nineteenth century (see the new translation edited by Flam and Flanders, 1991). Their economic metaphor was driven by primary foodstuffs: what economic historians now call the invasion of grains from the New World, driven by the sharp decline in transport costs, served to lower the relative price of grains in the old World (like Britain)

\footnotetext{
${ }^{2}$ This and the following seven paragraphs draw liberally on O'Rourke and Williams on (1992).
} 
and raise it in the New World (1ike America). Britain and the smaller economies on the continent did not respond to the challenge with tariffs, although the bigger economies on the continent did (1ike France, Germany and Italy: Kindleberger, 1951). What occured in the late nineteenth century was exactly the kind of exogenous relative price shock which is supposed to set factor-price convergence in motion. According to the FPE theorem, the invasion of grains should have tended to raise real wages in America while lowering them in Britain. Did it?

Actua11y, there are three questions here, not just one. First, were factor endowments really the key determinants of trade patterns in the late nineteenth century? Second, was there pronounced commodity price convergence in the late nineteenth century? Third, if the first two propositions hold, did commodity price convergence also make a significant contribution to the observed real wage convergence?

Gonsider the first question. Two recent and influential papers by economic historians have analyzed the determinants of comparative advantage in British and American manufacturing in the late nineteenth century. Nick Grafts and Mark Thomas (1986) find support for the Heckscher-Ohlin hypothesis, since endowments explain the pattern of trade in British manufacturing between 1910 and 1935, as we11 as the United States in 1909. Gavin Wright (1990) finds the same in accounting for the evolution of US trade patterns between 1879 and 1940. More recent1y, Antoni Estevadeordal (1992) has found more support based on a large sample of 18 countries around 1913. Indeed, the 1913 evidence is far more supportive of the Heckscher-Ohl in hypothesis (Estevadeora1, 1992, p. 9) than Edward Leamer (1984) was able to report on post World War II data. Finally, it seems relevant to note that William Whitney (1968) found no 
evidence of a Leontief Paradox in the US 1899 data.

Consider the second question. Economic historians have long been aware of the revolutionary decline in transport costs underlying overseas trade in the late nineteenth century. Douglass North (1958, p. 537) called the deline "radical" both for railroads and ocean shipping. Since Britain imported foodstuffs and raw materials, and since these bulk commodities "were fundamental beneficiaries of the cheapening transport costs" (p. 544), North thought it was clear that it contributed in Britain to "lower priced foodstuffs and therefore rising real wages, and to lowering in the cost of industrial raw materials" (p. 545) and therefore, we take it, rising rates of industrialization. Although North doesn't say so, symmetry suggests that real wages must have been lowered in the US while industrialization must have been suppressed, ceteris paribus.

When deflated by a general price index, North's freight rate index along American North Atlantic export routes dropped by more than 41 percent between 1870 and 1910. His wheat-specific American east coast real freight rate index fell by even more, about 53 percent. Similar evidence has been offered more recently by Knick Harley (1988), based on British overseas coal freight rates. Meanwhile, rail rates to the American interior fell, perhaps by even more (Williamson, 1974, p. 282).

In assessing the radical decline in overseas freight rates and the cost reductions along the rails between Chicago and New York, what mattered, of course, was its impact on the price convergence of tradables. Almost without exception, the literature has explored the question by looking at the international grain market. This is certainly true of Charles Kindleberger's (1951) important contribution to the debate over the 0ld World defensive 
policy response to the grain invasion, and it is also true of Knick Harley's (1980, 1986) writings on late nineteenth century transport, trade and settlement. It turns out, however, that Anglo-American price convergence was far more comprehensive. A recent paper by two of the present authors has shown that while Liverpool grain prices exceeded Chicago prices by 60.2 percent in 1870, the spread was only 14.2 percent in 1912 (O'Rourke and Williamson, 1992). The price gap for meat and animal fats declined from 93 percent to 18 percent over the same period. The price gap for iron products fell from 80 to 20 percent, cotton textiles from 14 to 1 percent, and so on. Quite clearly, there was dramatic convergence of tradable prices in the Atlantic economy between 1870 and World War I.

Consider now the third question. In an effort to assess the FPE theorem, the same computable general equilibrium (GGE) models that were used in Section IV to assess Anglo-American migrations were also used to assess the impact of price convergence ( $O^{\prime}$ Rourke and Williamson, 1992). ${ }^{3}$ The first results, which do not allow for any external capital flow response, are summarized in Panel A of Table 4. The table offers estimates of the impact of commodity price convergence on Anglo-American real wages and other factor prices for both the earlier 1870-1890 period as well as the full 1870-1910 period. Our interest here is in the real wage gap. The Anglo-American real wage gap declined in fact by 17.2 percentage points up to 1890. Table 4 (Panel A) implies that about two-thirds of that convergence can be assigned to commodity price equalization forces, about 12.2 percentage points. Over the full period 18701910 , it served to reduce the wage gap by about 26.6 percentage points, a

${ }^{3}$ The analysis which follows has also been confirmed by applying econometrics to a seven-country panel data set for the late 19th century (O'Rourke, Taylor and Williamson, 1993). 
figure which exceeds the actual measured convergence over the four decades as a whole suggesting that the effects of the superior American industrial performance was dominant after 1890 (consistent with Wright, 1990). In short, commodity price convergence played a significant role in contributing to real wage convergence up to 1890 , and in muting the divergence effects of superior American industrialization thereafter.

Note, in addition, that commodity price convergence served to erode relative capital scarcity in America. Compared with the rest of the economy, agriculture was less capital intensive in both America and Britain. Thus, the price shocks served to lower the return to capital in America (where, in response, the relative size of agriculture rose) and to raise it in Britain (where, in response, the relative size of agriculture fell). On net, commodity price convergence served to erode the rate of return gap (which favored capital-scarce America). These results suggest that if world capital markets had been perfectly integrated, commodity price convergence would have served by itself to accelerate accumulation in Britain relative to America, to increase the capital-labor ratio in Britain relative to America, thus to reinforce real wage convergence. Panel B of Table 4 suggests, however, that such supportive accumulation responses would have had only a modest impact: an (extreme) assumption of perfectly elastic world capital flows in response to the price shocks implies that induced real wage convergence up to 1910 would have been 31.5 percentage points (perfectly elastic capital flows) rather than 26.6 percentage points (no capital flows). Thus, our results are robust to

The induced external capital flows underlying the simulations in Panel B of Table 4 for the full 1870-1910 period have a trivial impact on the rate of accumulation in the USA while they only increase the rate of accumulation in Britain by about 0.2 percent per annum. These are upper bounds on the estimated capital migration response to the Anglo-American commodity price 
assumptions about world capital markets, at least in terms of the FPE theorem.

\section{ENDOGENIZING MIGRATION}

The previous section shows that Heckscher and Ohlin were right: commodity price convergence served to erase some of the Anglo-American wage gap in the late nineteenth century. But we should remember that international trade and labor migrations are partial substitutes: if commodity price convergence served to erase part of the Anglo-American wage gap, then it should also have diminished the size of the mass migrations. In short, by failing to allow migration to respond to Anglo-American wage gaps, we have overstated the net impact of commodity price convergence. The interesting question, of course, is "how much?" This section offers an answer by endogenizing United States immigration and British emigration.

We rely on two studies which have estimated US immigrant (Williamson, 1974, p. 236) and British emigrant (Hatton, 1992) elasticities in response to changes in home wages, and when embedded in the model they convert migrant elasticities to migrant-induced labor force elasticities.

A comparison of Panel $C$ with Panel A of Table 4 shows how little endogenous migration responses diminish the net impact of commodity price convergence. This, of course, does not imply that migration had a weak impact on real wage convergence since, indeed, Table 2 has already shown the contrary. Rather, it simply suggests that the endogenous migrant-induced labor force responses to these price shocks were modest.

convergence, so they give some sense of the small interaction between global commodity and capital markets implied by the experiments. 


\section{VII . WHAT EXPLAINS THE LATE NINETEENTH ANGLO-AMERICAN CONVERGENCE?}

Factor prices converged among the currently-industrialized OECD countries between 1870 and World War I. It was manifested in relatives -- the wage/rental ratio -- and in absolutes -- the real wage. The convergence was as dramatic as it has been in the more familiar post-World War II decades. Furthermore, the convergence was driven primarily by the erosion of the average wage gap between the New World and the 0ld, rather than by convergence within either of the two regions. While the real wage convergence between the resource-rich and labor-scarce United States and resource-poor and laborabundant Britain was far less spectacular than was true for the rest of the OECD sample, and while it was far greater in the first half than in the second half of the period, some Anglo-American convergence did take place.

How much of the Anglo-American convergence in the late nineteenth century was due to the mass migrations? How much of it was due to commodity price convergence? And how much of it to the residual forces of resource accumulation and productivity advance? Table 5 offers our tenative answers. The first row reports the observed real wage convergence, the US losing some of its real wage advantage between 1870 and 1890 , while recovering most of that lost ground between 1890 and 1910. The second row reports the independent impact of US immigrations and British emigrations on the Anglo-American wage gap, netting out the influence of endogenous external capital flows, that is, netting out the fact that capital chased after labor (from Table 2, Panel B). Row 2 offers a lower bound of the impact of the mass migrations since it makes the extreme assumption of pexfectly elastic capital flow responses to rate of return differentials in the two economies. The third row reports the impact of 
these commodity price convergence factors were weaker for many other European trading partners (due, of course, to protection: O'Rourke, Taylor and Williamson, 1993). "Yes" in the sense that old World mass emigrations were even bigger in Ireland, Italy and Norway than in Britain, and in the sense that New World mass immigrations were even bigger in Argentina and Canada than in the USA. "Maybe" in the sense that those residual factors were likely to have favored convergence for other pairs of countries, poor countries catching up technologically with the rich. What we need, of course, are more studies like this one to find out whether the late nineteenth century Anglo-American convergence forces were replicated at the global level. 


\section{REFERENCES}

Abramovitz, M. [1961], "The Nature and Significance of Kuznets Cycles," Economic Development and Cultural Change 9 (April): 225-48.

Abramovitz, M. [1968], "The Passing of the Kuznets Cycle," Economica 35

(November): $349-67$.

Abramovitz, M. [1986], "Catching Up, Forging Ahead, and Falling Behind," Journal of Economic History 46 (June): 385-406.

Baumol, W. J., S. Blackman, and E. N. Wolff [1989], Productivity and American Leadership: The Long View (Cambridge: MIT Press).

Borjas, G. J. [1990], Friends or Strangers? The Impact of Immigrants on the U.S. Economy (New York: Basic Books).

Borjas, G. J. [1991], "Immigrants in the U.S. Labor Market: 1940-80," American Economic Review 81 (May): $287-91$.

Borjas, G. J. and R. B. Freeman (eds.) [1992], Immigration and the Workforce (Chicago: University of Chicago Press).

Crafts, N. F. R. and M. Thomas [1986], "Comparative Advantage in UK Manufacturing Trade 1910-35," Economic Journal 96 (September): 629-45.

DeLong, J. B. [1988], "Productivity Growth, Convergence, and Welfare: A Comment," American Economic Review 78 (December): 1138-54.

Easterlin, R. A. [1968], Population, Labor Force, and Long Swings in Economic Growth (New York: National Bureau of Economic Research).

Edelstein, M. [1982], Overseas Investment in the Age of High Imperialism (New York: Columbia University Press).

Estevadeordal, A. [1992], "Comparative Advantage at the Turn of the Century," mimeo., Harvard University (November). 
Feinstein, C. H. [1976], Statistical Tables of National Income, Expenditure and Output of the U.K. (Cambridge: Cambridge University Press).

Flam, H. and M. J. Flanders (eds.) [1991], Heckscher-Ohlin Trade Theory (Cambridge, Mass.: MIT Press).

Gerschenkron, A. [1952], "Economic Backwardness in Historical Perspective," in B. F. Hoselitz (ed.), The Progress of Underdeveloped Areas (Chicago: University of Chicago Press).

Goldin, C. [1993], "The Political Economy of Immigration Restriction in the United States, 1890 to 1921 ," paper presented at the Conference on Historical Political Economy, NBER, Cambridge, Mass. (May 20-21). Greenwood, M. J. and J. M. McDowe11 [1986], "The Factor Market Consequences of U.S. Immigration," Journal of Economic Literature 24 (December): 173872.

Harley, C. K. [1980], "Transportation, the World Wheat Trade, and the Kuznets Cycle, 1850-1913," Explorations in Economic History 17 (July): 218-50. Harley, C. K. [1986], "Late Nineteenth Century Transportation, Trade and Settlement," in W. Fischer, R. M. McInnis and J. Schneider (eds.), The Emergence of a World Economy 1500-1914: Part II (Stuttgart): 593-617. Harley, C. K. [1988], "Ocean Freight Rates and Productivity, 1740-1913: The Primacy of Mechanical Invention Reaffirmed," Journal of Economic History 48 (December): $851-76$.

Hatton. T. J. [1992], "A Model of U. K. Emigration, 1870-1913," Department of Economics, University of Essex, mimeo.

Hatton T. J. and J. G. Williamson [1992a], "International Migration and World Development: A Historical Perspective," National Bureau of Economic Research, DAE Working Paper No. 41 (September). 
Hatton, T. J. and J. G. Williamson [1992b], "What Drove Mass Migrations from Europe in the Late Nineteenth Century?", Harvard Institute of Economic Research., Discussion Paper No. 1614 (October).

Karlstrom, U. [1985], Economic Growth and Migration During the Industrialization of Sweden: A General Equilibrium Approach (Stockholm: Stockholm School of Economics).

Kelley, A. C. [1988], "Economic Consequences of Population Change in the Third World," Journal of Economic Literature 26 (December): 1685-1728.

Kendrick, J. W. [1961], Productivity Trends in the United States (Princeton, N.J.: Princeton University Press).

Kindleberger, C. P. [1951], "Group Behavior and International Trade," Journal of Political Economy 59 (February-December): 30-46.

Kuznets, S. [1952], Income and Wealth of the United States: Trends and Structure: Income and Wealth Series II (Cambridge: Bowes and Bowes). Leamer, E. E. [1984], Sources of International Comparative Advantage (Cambridge, Mass.: MIT Press).

Lindert, P. H. [1978], Fertility and Scarcity in America (Princeton, N.J.: Princeton University Press).

McCloskey, D. N. [1970], "Did Victorian Britain Fail?" Economic History Review 23 (December): 446-59.

Mitche11, B. R. and P. Deane [1962], Abstract of British Historical Statistics (Cambridge: Cambridge University Press).

Neal, L. and P. Uselding [1972], "Immigration: A Neglected Source of American Economic Growth, 1790-1912," Oxford Economic Papers 24 (March): 68-88.

Nelson, R. R. and G. Wright [1992], "The Rise and Fall of American Technological Leadership," Journal of Economic Literature 30 (December): 
$1931-64$.

North, D. C. [1958], "Ocean Freight Rates and Economic Development 1750-1913," Journal of Economic History 18 (December): 537-55.

O'Rourke, K. and J. G. Williamson [1992], "Were Heckscher and OhIin Right? Putting the Factor-Price-Equalization Theorem Back into History," Discussion Paper Number 1593, Harvard Institute of Economic Research (May).

O'Rourke, K., A. M. Taylor and J. G. Williamson [1993], "Land, Labor and the Wage-Rental Ratio: Factor Price Convergence in the Late Nineteenth Century," Discussion Paper No. 1629, Harvard Institute of Economic Research (March).

Pope, D. and G. Withers [1990], "Do Migrants Rob Jobs from Locals? Lessons from Australian History," Australian National University, Working Paper No. 133 (March).

Romer, P. M. [1986], "Increasing Returns and Long-Run Growth," Journal of Political Economy 94: $1002-37$.

Rutherford, T. [1988], General Equilibrium Mode1ing with MPS/GE (Department of Economics, University of Western Ontario).

Simon, M. [1967], "The Pattern of New British Portfolio Foreign Investment, 1865-1914," in J. H. Adler (ed.), Capital Movements and Economic Development (London: Macmi11an).

Simon, J. L. [1989], The Economic Consequences of Immigration (Cambridge, Mass: Blackwel1).

Taylor, A. M. [1992], "Argentine Economic Growth in Comparative Perspective," PhD thesis, Harvard University (June).

Temin, P. [1966], "Labor Scarcity and the Problem of American Industrial 
Efficiency in the 1850s," Journal of Economic History 26 (September): 277-98.

Thomas, B. [1954], Migration and Economic Growth (Cambridge: Cambridge University Press).

U.S.Department of Commerce [1975], Historical Statistics of the United States (Washington, D.C.: USGPO).

Whitney, W. G. [1968], "The Structure of the American Economy in the Late Nineteenth Century." Ph.D. dissertation, Harvard University.

Wicksel1, K. [1882], Om utvandringen: Dess betydelse och orsaker (Stockholm: Albert Bonniers Forlag).

Williamson, J. G. [1974], Late Nineteenth-Century American Development (Cambridge: Cambridge University Press).

Williamson, J. G. [1990], Coping with City Growth During the British Industrial Revolution (Cambridge: Cambridge University Press). Williamson, J. G. [1991 and 1992], "The Evolution of Global Labor Markets in the First and Second World Since 1830: Background Evidence and Hypotheses." The [1992] version is National Bureau of Economic Research, DAE Working Paper No. 36 (February). The [1991] version is Discussion Paper No. 1571, Harvard Institute of Economic Research (October).

Wolff, E. N. [1991], "Capital Formation and Productivity Convergence Over the Long Term," American Economic Review 81, 3 (June): 565-79.

Wright, G. [1990], "The Origins of American Industrial Success, 1879-1940," American Economic Review 80 (September): 651-68.

Zevin, R. B. [1992], "Are World Financial Markets More Open? If So Why and With What Effects?" in T. Banuri and J. Schor (eds.), Financial Openness 
and National Autonomy (London: Oxford University Press). 
Table 1

Three Estimates of the Impact of 19th Century International Migrations on Real Wages

\begin{tabular}{lcccc}
\hline $\begin{array}{l}\text { Migration } \\
\text { Direction }\end{array}$ & $\begin{array}{c}\text { Country } \\
\text { and Period }\end{array}$ & $\frac{\text { Impact on Real Wages }}{\text { Total }}$ & per Decade & Source \\
\hline Emigration & Sweden 1871-90 & +9.48 & +4.98 & Karlstron [1985], p. 155 \\
Immigration & Britain 1821-51 & -4.1 & -1.4 & Williamson [1990], p. 153 \\
Immigration & USA 1870-1910 & -9.9 & -2.5 & Williamson [1974], p. 249 \\
\hline
\end{tabular}




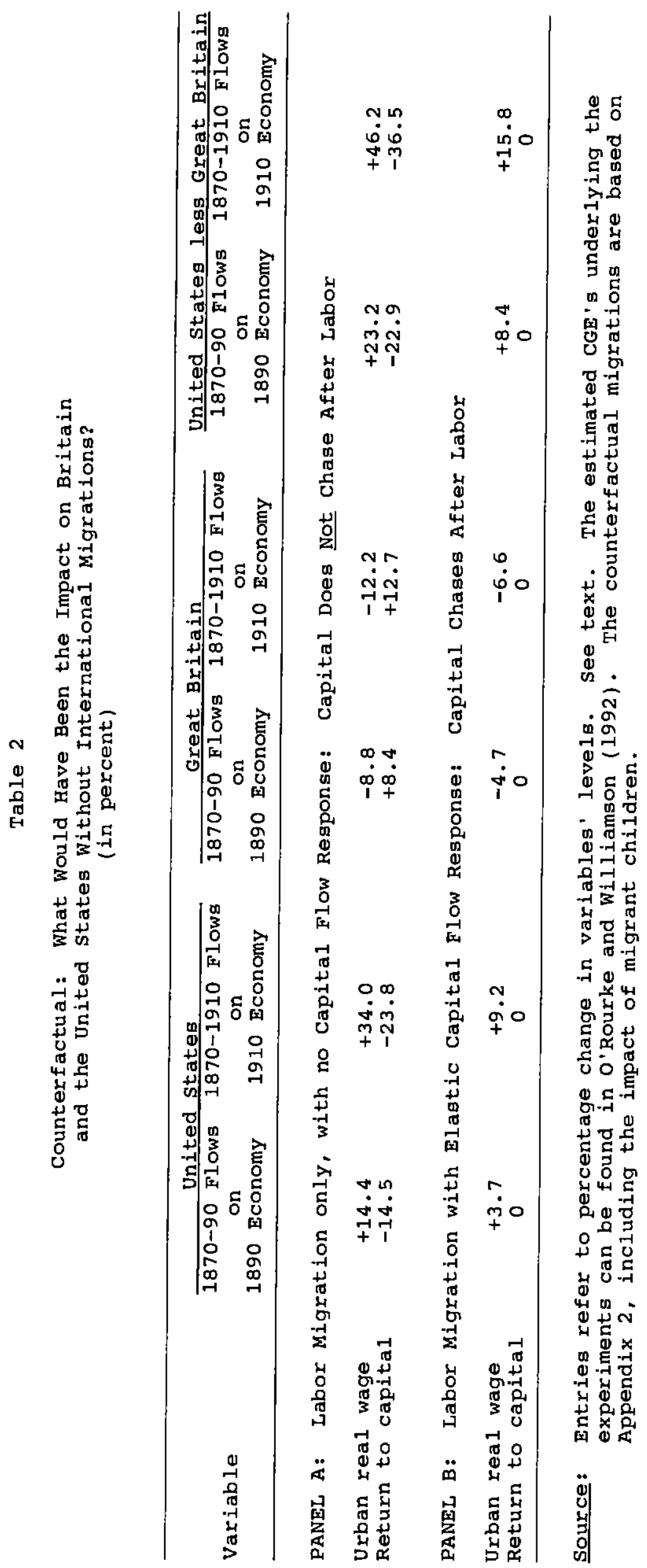


Table 3

Impact of International Migration and Capital Flows on Capital-Deepening in Britain and America, 1870-1910:

per annum growth (in percent)

\begin{tabular}{|c|c|c|c|c|}
\hline- & (1) & (2) & (3) & (4) \\
\hline $\begin{array}{l}\text { Country and } \\
\text { Period }\end{array}$ & $\mathrm{NFI} / \mathrm{K}$ & MIG/L & $=(1)-(2)$ & Actual $\mathrm{K}$ \\
\hline United State & & & & \\
\hline $\begin{array}{l}1870-1890 \\
1890-1910 \\
1870-1910\end{array}$ & $\begin{array}{r}0.40 \\
-0.09 \\
0.03\end{array}$ & $\begin{array}{l}0.69 \\
0.94 \\
0.82\end{array}$ & $\begin{array}{l}-0.29 \\
-1.03 \\
-0.79\end{array}$ & $\begin{array}{l}1.96 \\
2.08 \\
2.02\end{array}$ \\
\hline
\end{tabular}

Great Britain

$\begin{array}{lllll}1870-1890 & -2.23 & -0.52 & -1.71 & 0.53 \\ 1890-1910 & -2.14 & -0.24 & -1.90 & 0.82 \\ 1870-1910 & -2.15 & -0.38 & -1.77 & 0.68\end{array}$

Sources and notes.

(1) United States: NFI = net foreign investment (+ inflow, - outflow, current \$: US Bureau of the Census, 1975, series U18-U24, pP. 867-8); K = net reproducible capital stock (current $\$$ : Kendrick, 1961, Tables A-XV and A-XVI, pp. 320-4 for constant \$; Kendrick, 1961, Tables A-IIa and A-IIb, Pp. 293-297, for prices to convert to current \$). Great Britain: NFI = net foreign investment (current $f s$ : Edelstein, 1982, Table Al.1, PP. 313-4); K = net reproducible capital stock (current $£ s$ : Feinstein, 1976, Table 46, pp. T103T104).

(2) United States and Great Britain: $M I G / L$ is the estimated impact of migrants and their children on the labor force (Appendix 2).

(4) United States: reproducible capital stock in 1929 prices (Kendrick, 1961, Tables A-XV and A-XVI, PP. 320-324; 1abor force from Appendix 2. Great Britain: reproducible capital stock in 1900 prices (Feinstein, 1976, Table 43, pp. T96-T97); labor force from Appendix 2 .

Wolff (1991, p. 571) estimates a rate of British capital-deepening of 0.83 for the period 1880-1913 (compared with our estimate of 0.68 for 1870-1910) and a rate of American capital-deepening of 2.61 for the period 1880-1913 (compared with our estimate of 2.02 for 1870-1910). 
Table 4

Counterfactual: Did Anglo-American Commodity Price Equalization Contribute to Factor Price Convergence?

\begin{tabular}{|c|c|c|c|}
\hline \multirow[b]{2}{*}{ Variable } & \multicolumn{3}{|c|}{ Price shock apportioned between: } \\
\hline & $\begin{array}{l}\text { United } \\
\text { States }\end{array}$ & $\begin{array}{c}\text { Great } \\
\text { Britain }\end{array}$ & $\begin{array}{c}\text { Great Britain } \\
\text { minus } \\
\text { United States }\end{array}$ \\
\hline
\end{tabular}

Panel A: Without International Capital Flows

\begin{tabular}{|c|c|c|c|}
\hline $\begin{array}{l}\text { Urban real wage } \\
\text { Land real rent } \\
\text { Return to capital }\end{array}$ & $\begin{array}{l}+0.1 \\
+3.5 \\
-2.4\end{array}$ & $\begin{array}{r}+8.0 \\
-26.0 \\
+7.5\end{array}$ & $\begin{array}{r}+7.9 \\
-29.5 \\
+9.9\end{array}$ \\
\hline Wage rental ratio & -3.3 & +45.9 & +49.2 \\
\hline Full Period: $1870-1910$ & & & \\
\hline $\begin{array}{l}\text { Urban real wage } \\
\text { Land real rent } \\
\text { Return to capital }\end{array}$ & $\begin{array}{r}+0.3 \\
+11.5 \\
-7.9\end{array}$ & $\begin{array}{l}+19.3 \\
-50.7 \\
+18.4\end{array}$ & $\begin{array}{l}+19 \cdot 0 \\
-62 \cdot 2 \\
+26 \cdot 3\end{array}$ \\
\hline Wage rental ratio & -10.1 & +142.1 & +152.2 \\
\hline
\end{tabular}

PANEL B: With Perfectly Elastic International Capital Flows

\begin{tabular}{|c|c|c|c|}
\hline $\begin{array}{l}\text { Urban real wage } \\
\text { Iand real rent }\end{array}$ & $\begin{array}{l}+1.0 \\
+3.7\end{array}$ & $\begin{array}{l}+11.1 \\
-26.0\end{array}$ & $\begin{array}{l}+10.1 \\
-29.7\end{array}$ \\
\hline Wage rental ratio & -2.6 & +50.1 & +52.7 \\
\hline \multicolumn{4}{|l|}{ Full Period: $1870-1910$} \\
\hline $\begin{array}{l}\text { Urban real wage } \\
\text { Land real rent }\end{array}$ & $\begin{array}{r}+1.7 \\
+11.8\end{array}$ & $\begin{array}{l}+25.4 \\
-50.7\end{array}$ & $\begin{array}{l}+23.7 \\
-62.5\end{array}$ \\
\hline Wage rental ratio & -9.1 & +154.5 & +163.6 \\
\hline
\end{tabular}

PANEL C: With Endogenous International Migration Responses

\begin{tabular}{|c|c|c|c|}
\hline $\begin{array}{l}\text { Urban real wage } \\
\text { Land real rent } \\
\text { Return to capital }\end{array}$ & $\begin{array}{l}+0.1 \\
+3.5 \\
-2.4\end{array}$ & $\begin{array}{r}+6.2 \\
-25.7 \\
+10.8\end{array}$ & $\begin{array}{r}+6 \cdot 1 \\
-29 \cdot 2 \\
+13 \cdot 2\end{array}$ \\
\hline Wage rental ratio & -3.3 & +43.0 & +46.3 \\
\hline Full Period: $1870-1910$ & & & \\
\hline $\begin{array}{l}\text { Urban real wage } \\
\text { Land real rent } \\
\text { Return to capital }\end{array}$ & $\begin{array}{r}+0.2 \\
+11.6 \\
-7.8\end{array}$ & $\begin{array}{l}+13.7 \\
-50.1 \\
+28.8\end{array}$ & $\begin{array}{l}+13 \cdot 5 \\
-61 \cdot 7 \\
+36 \cdot 6\end{array}$ \\
\hline Wage rental ratio & -10.2 & +128.0 & +138.2 \\
\hline
\end{tabular}

Source: Panel $A$ and $B$ are revisions of $O$ 'Rourke and Williamson [1992], Tables 2 and 3. Panel $\mathrm{C}$ is calculated by endogenizing migration. 
Table 5

The Sources of Late Nineteenth Century Anglo-American

Real Wage Convergence: Wage Gap (in percent)

Source

1870

1890

1910

1. Wage gap trend observed (Williamson, 1992, Table A2)

$66.7 \%$

$49.5 \%$

$61.9 \%$

Due to:

2. Post-1870 labor migration, net

66.7

53.3

42.0

of capital flow response

(Table 2, Panel B)

3. Post-1870 commodity price convergence, net of capital

flow and migration response

(Table 4, Panel C)

4. Both (2) and (3)

66.7

39.4

15.1

5. Residual: due to post- 1870

66.7

84.1

163.5

productivity advance and

resource accumulation

favoring the US

Notes: Row (1) reports the percent by which real wage rates in the USA exceeded Britain in 1870, 1890 and 1910. Row (2) can be illustrated by the 1890 calculation: since Table 2, Panel B, reports that the US wage rate would have increased by 3.7 percent in the absence of immigration (to $172.9=$ $1.037 \times 166.7)$, it follows that immigration by itself served to reduce the US real wage rate by 3.6 percent $([166.7-172.9] / 172.9=-.036)$, that is from 166.7 (Britain = 100) in 1870 to 160.7 in $1890(=.964 \times 166.7)$; since Table 2, Panel $B$, reports that the British wage rate would have decreased by 4.7 percent in the absence of emigration (to $95.3=.953 \times 100$ ), it follows that emigration by itself served to raise the British real wage rate by 4.9 percent ( [ $100-95.3] / 95.3=+.049)$, that is from 100 in 1870 to 104.9 in 1890 ; thus, migration by itself served to reduce the wage gap from 66.7 percent in 1870 to 53.2 percent in $1890([160.7-104.9] / 104.9=.532)$. Row (3) can also be illustrated by the 1890 calculation: Table 4, Panel $\mathrm{C}$, reports that the US wage rate was increased by 0.1 percent by commodity price convergence to 166.9 in $1890(166.7 \times 1.001=166.9)$; Table 4, Panel $C$, reports that the British wage rate was increased by 6.2 percent to 106.2 in 1890 ; thus, commodity price convergence by itself served to reduce the wage gap from 66.7 percent in 1870 to 57.2 percent in $1890([166.9-106.2] / 106.2=.572)$. Row (4) multiplies the two effects in Rows 2 and 3: due to these two forces, the Us real wage rate in 


\section{Notes to Table 5 (continued):}

1890 would have been $160.9(=.964 \times 1.001 \times 166.7)$, the British real wage rate would have been $111.4(=1.049 \times 1.062 \times 100)$, and the wage gap would have been 44.4 percent $([160.9-111.4] / 111.4=.444)$. Row (5) calculates the residual: Row (1) reports that the Us real wage rate fell (relative to Britain=100) from 166.7 to 149.5 between 1870 and $1890,17.2$ points, while migration and commodity price convergence pushed it down from 166.7 to $160.9,5.8$ points, for a residual of 11.4 points, or to 155.3 in $1890(166.7-11.4=155.3)$; since the British real wage rate is taken as the base, it stays at 100 , Row (4) reports that migration and commodity price convergence pushed up the British real wage rate from 100 to $111.4,11.4$ points, for a residual of -11.4 points, or 88.6 in 1890 ; thus, residual forces served to raise the wage gap from 66.7 percent in 1870 to 75.3 percent in $1890([155.3-88.6] / 88.6=$ $.753)$. 


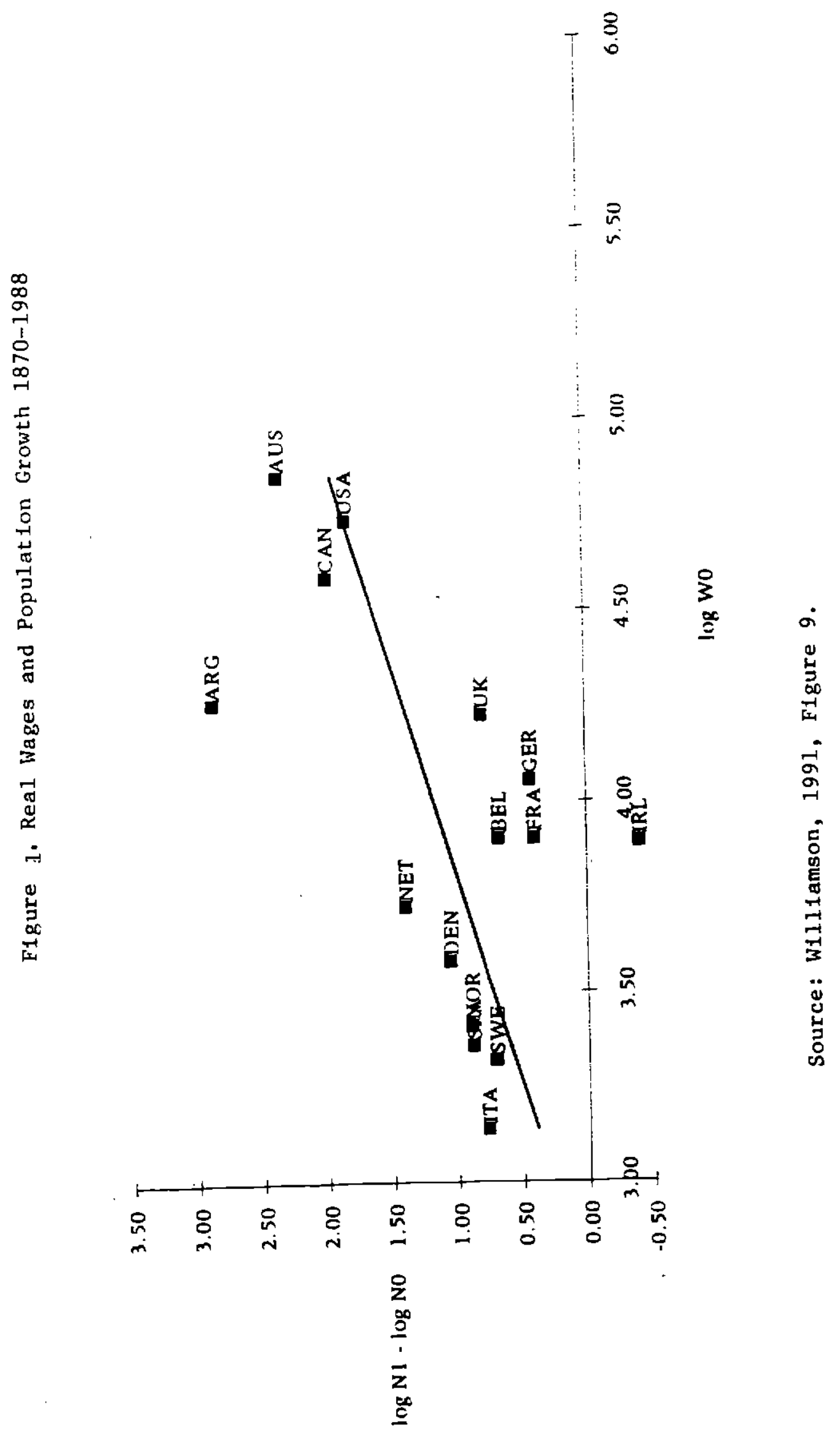




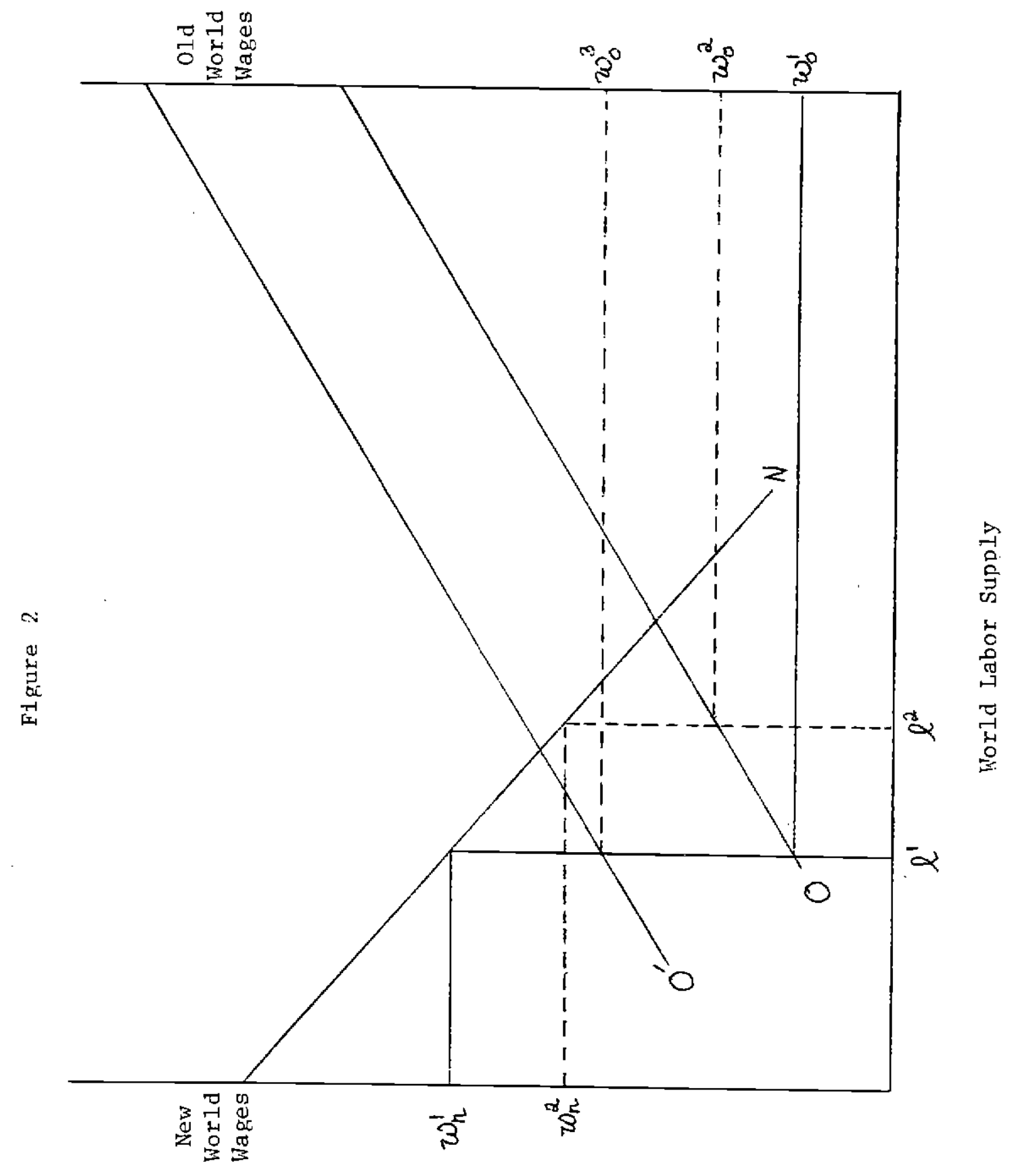




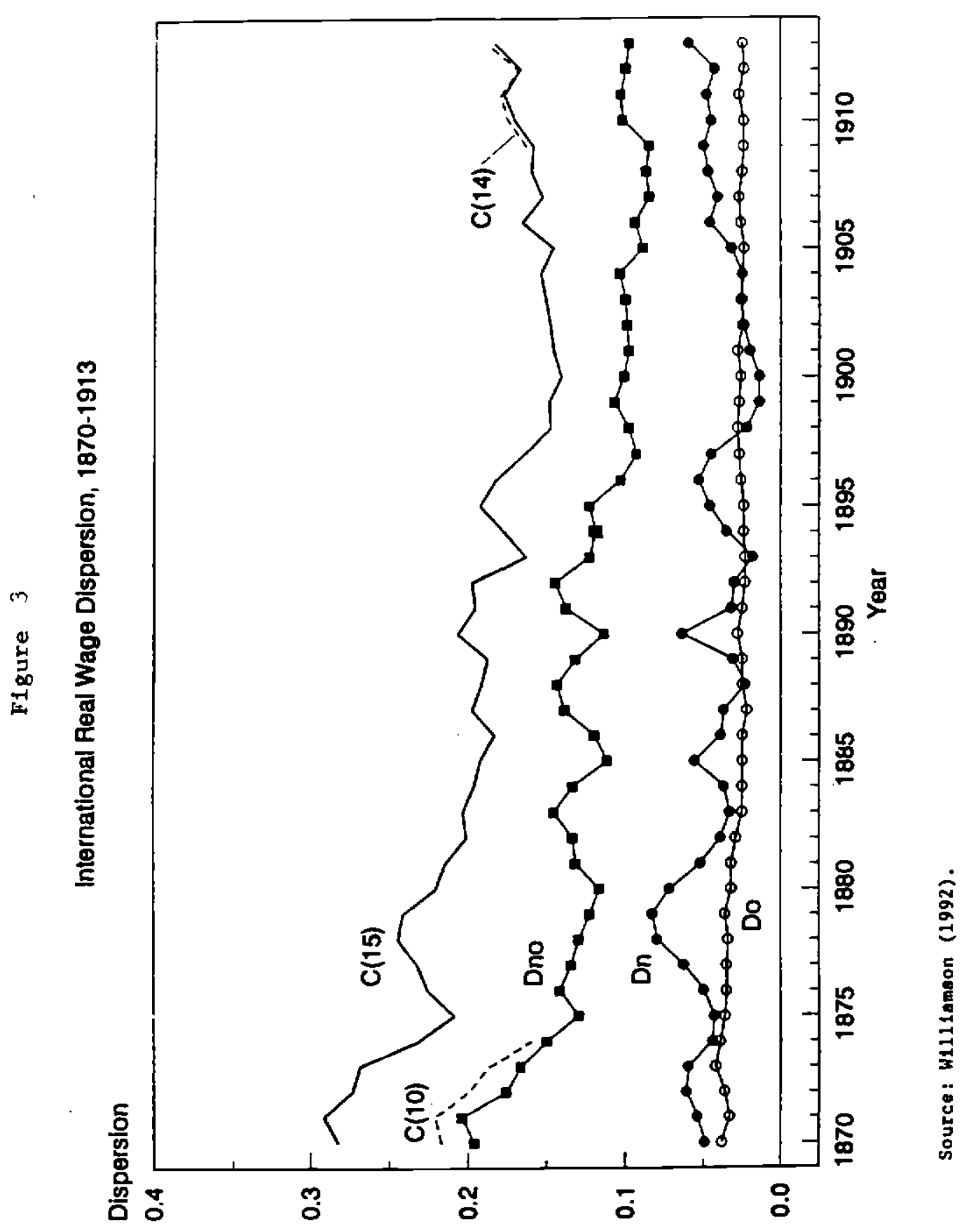


While they are very similar, the us model is more complicated than the British in several ways. This appendix will therefore explain the former in some detail (O'Rourke and Williamson, 1992). The major simplifications made to the latter are then indicated; the text and the Us model exposition here should make the structure of the British model clear.

\section{The US Model}

The Us model is in the neoclassical, general equilibrium tradition. It has three components. Sector supplies obey standard production functions; output and factor prices are endogenously determined. Each commodity has a price, which may or may not be endogenous, depending on whether the good is tradable in world markets. Consumers are constrained by endowments and maximize some utility function; their income and expenditures are endogenous. The alogrithm used here, MPS $\backslash G E$, is taken from Rutherford (1988). Production and utility functions are specified; the algorithm then calculates cost, factor demand and commodity demand. Equilibrium is defined by a set of prices, activity levels and incomes such that: (i) no sector earns a positive profit; (ii) supply minus demand for each commodity is nonnegative; and (iii) income from factor endowments is fully distributed.

\section{Production}

There are four production activities: food (A); agricultural intermediates (I); non-food manufacturing $\left(M_{A}\right)$; and services (S). In addition to the four commodities produced, there are three primary factors of production -- land (R), raw labor $\left(I_{R}\right)$ and capital (K); two 'produced' factors 
of production -- agricultural labor $\left(L_{A}\right)$ and non-agricultural labor $\left(L_{N A}\right)$; and two imported goods -- tropical goods ( $T$ ) and imported manufactures $\left(M_{F}\right)$. Finally, an artificial good, 'foreign exchange', is used in modelling trade flows, and serves as the numeraire.

MPS \GE insists that production functions be C.E.S., of which CobbDouglas is a special case. (Given the elasticity of substitution, all the parameters of such functions can be conveniently estimated from a microconsistent data set.) Production in both agricultural sectors is CobbDouglas, production in the other two sectors C.E.s.:

$$
\begin{aligned}
& A=L_{A A} \oplus A L_{K_{A}} \oplus A K_{R_{A}} \oplus A R \\
& I=L_{A I} \oplus I L_{K_{I}} \oplus I K_{R_{I}} \oplus I R \\
& M_{A}=\left[a_{M L} L_{N A M}{ }^{\tau M}+a_{M K} K_{M}^{\tau M}+a_{M I} I_{M}^{\tau M}+a_{M T} T_{M}^{\tau M}+a_{M A} A_{M}^{\tau M}\right]^{1 / \tau M} \\
& S=\left[a_{S L} L_{N A S}{ }^{\tau S}+a_{S K} k_{S}{ }^{\tau S}+a_{S M} M_{A S} \tau S\right]^{1 / \tau S}
\end{aligned}
$$

where the left-hand side variables are outputs, $x_{i}$ is the input of commodity $x$ into sector $i$, the output elasticities, $\Theta_{i j}$, always sum to one; the $a_{i j}$ 's are constants; and

$$
\begin{aligned}
& \tau_{M}=\left(\sigma_{M}-1\right) / \sigma_{M} \\
& \tau_{S}=\left(\sigma_{S}-1\right) / \sigma_{S}
\end{aligned}
$$

where the $\sigma \cdot s$ are pairwise elasticities of substitution.

Firms minimize costs, which generates factor demand and cost functions. In the Cobb-Douglas case, where $Q$ is output, $x_{i}$ is the input of factor $i$, and $w_{i}$ is the price of factor $i$, production is described by (choosing units so that the constant term is unity)

$$
Q=\Sigma_{i} x_{i}{ }^{\ominus i}
$$

the demand for factor i equals

$$
x_{i}\left(\left\{w_{j}\right\}, Q\right)=Q\left(\Theta_{i} / w_{i}\right) \Sigma_{j}\left(w_{j} / \Theta_{j}\right)^{\theta j}
$$

and the cost function is given by (where $B$ is a constant) 


$$
c\left(\left\{w_{i}\right\}, Q\right)=B Q \Sigma_{i}\left(w_{i} / \odot_{i}\right)^{\ominus i}
$$

In the more general C.E.S. case, production is given by

$$
Q=\left[\Sigma_{i} a_{i} x_{i}^{\tau}\right]^{1 / \tau}
$$

where $\tau=(\sigma-1) / \sigma$, and factor demands are given by

$$
X_{i}\left(\left\{w_{j}\right\}, Q\right)=Q\left[\left(a_{i} / w_{j}\right)\left\{\Sigma_{j}\left(a_{j} \sigma_{j}^{1-\sigma}\right)\right\}^{1 / 1-\sigma}\right]^{\sigma}
$$

and the cost function is

$$
c\left(\left\{w_{i}\right\}, Q\right)=Q\left[\Sigma_{i}\left(w_{i} / a_{i}\right)^{1-\sigma}\right]^{1 / 1-\sigma}
$$

The model assumes perfect competition; thus, in each sector price equals unit cost (which depends uniquely on factor prices, given constant returns to scale):

$$
\begin{gathered}
p_{A}=c_{A}\left(w_{A}, r, d\right) \\
p_{I}=c_{I}\left(w_{A}, r, d\right) \\
p_{M A}=c_{M A}\left(w_{N A}, r, p_{I}, p_{T}, p_{A}\right) \\
p_{S}=c_{S}\left(w_{N A}, r, p_{M A}\right)
\end{gathered}
$$

Here $p_{i}$ stands for the price of good $i ; w_{A}$ and $w_{N A}$ are the wages of agricultural and non-agricultural labor respectively; $r$ and $d$ are the returns to capital and land respectively; and the $c_{i}$ functions are unit cost functions as in (9) and (12) above.

Equations (13) through (16) incorporate the model's assumptions about factor mobility across sectors. Capital is perfectly mobile across all sectors. Land and agricultural labor are perfectly mobile between $\mathrm{A}$ and $\mathrm{I}$. Non-agricultural labor is perfectly mobile between manufacturing and services. Labor is, however, imperfectly mobile between agriculture and the rest of the economy .

\section{Rural-Urban Migration}

By allowing labor be less than perfectly mobile between sectors, rural- 
urban wage gaps are determined endogenously. Workers are endowed with 'raw' labor, which, by their migration decisions, is then transformed into agricultural and non-agricultural labor via a pseudo-production function, ( $L_{A}$, $\left.L_{N A}\right)=f\left(I_{R}\right)$. Collectively, potential migrants solve the following problem: $\operatorname{maximize} w_{A} L_{A}+w_{N A} L_{N A} s \cdot t$.

$$
\left[\delta_{A} I_{A}(\mu-1) / \mu+\delta_{N A} L_{N A}(\mu-1) / \mu\right]^{\mu / \mu-1}=I_{R}
$$

where $I_{\mathbf{R}}$ is the fixed endowment of raw labor, and $\mu$ is the constant elasticity of transformation of this joint production function, which determines how sensitive the intersectoral allocation of labor is to changes in the urbanrural wage gap. Their solution to this problem is:

$$
L_{A}=I_{R}\left[w_{A} / \delta_{A} \Gamma\right]^{\mu} ; L_{N A}=I_{R}\left[w_{N A} / \delta_{N A} \Gamma\right]^{\mu}
$$

where $\Gamma=\left[\delta_{A}^{\mu} w_{A}^{1-\mu}+\delta_{N A}^{\mu} w_{N A}^{1-\mu}\right]^{1 / 1-\mu}$.

Since the worker is endowed with raw labor, we need to determine the price of raw labor, $w_{R} ;$ given $w_{A}$ and $w_{N A}$ (and hence, via (17), $I_{A}$ and $L_{N A}$ ), we can calculate it from the zero-profit condition in the migration 'sector':

$$
w_{R} L_{R}=w_{A} L_{A}+w_{N A} L_{N A}
$$

\section{Trade Flows}

Pseudo-production functions are also used to model trade flows. Export sectors convert the export good into foreign exchange, and import sectors convert foreign exchange into import goods. In the benchmark equilibrium, the us ran a trade deficit. The us consumer is therefore endowed with enough foreign exchange to allow her to finance this deficit. This (together with the assumption that 'foreign exchange' is the numeraire) amounts to assuming that the nominal trade deficit is exogenous. This is of course unsatisfactory; but it is no more convincing to assume, for example, that trade is always balanced, or that the real value of the deficit is exogenous. 
As is well known, an intertemporal model would be required to model the current account rigorously; in the context of a static model, some ad hoc assumption is required.

The US is assumed to be 'small' in the markets for food, foreign manufactures and tropical goods; thus prices are exogenous. This is modelled by allowing exports or imports to be converted into foreign exchange at a fixed ratio. Let $E_{i}$ and $I_{i}$ stand for exports and imports of good $i$ respectively, and let $F_{i}$ denote the amount of foreign exchange used as an input into, or derived as an output from, the relevant trade sector:

\section{sector}

Food exports

Manufactured imports

Tropical good imports

\section{Output}

$\mathbf{F}_{\mathrm{A}} \quad=$

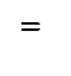

$I_{H}=$

$I_{T}$

\section{Input}

$\underline{p}_{A} E_{A}$

$\mathbf{F}_{M} / \underline{p}_{M F}$

$=\quad F_{T} / \underline{p}_{T}$

The price-cost equations for these three sectors tie down the exogenous prices of these three goods; it remains to determine the level of exports or imports of the goods.

The US is assumed to be 'big' in cotton, so cotton exports cannot be modelled in this way. The more cotton the Us exports, the lower will be the price of cotton. Thus, the production function converting cotton exports into foreign exchange will exhibit decreasing rather than constant returns to scale. This fact is incorporated in the following way:

$$
F_{I}=A E_{I}{ }^{\alpha}{ }^{1-\alpha}
$$

where $A$ is a constant and $\mathrm{Z}$ is a fictitious factor of production. The factor is in fixed supply, which is what generates the decreasing returns to scale. By 'minimizing costs' in this sector, a constant elasticity foreign demand for 
US cotton is generated:

$$
E_{I}=C p_{I E}^{\beta}
$$

where $C$ is a constant, $\beta$ is the elasticity of demand and $p_{I E}$ is the price of Us cotton abroad. Transport costs in this sector are explicitly modelled by assuming that they act as a tax $t$ on exports, the revenue from which accrues to the US consumer (that is, we assume that shipping receipts went to US nationals). The domestic and foreign price of intermediates are, of course, related as follows: "J

$$
P_{\text {IE }}=p_{I}(1+t)
$$

Finally, services are non-traded; domestic demand equals domestic supply .

Demand

The representative consumer is endowed with raw labor, capital, and land. In addition, she is endowed with enough foreign exchange to run the exogenous trade deficit, and she consumes manufactured goods (both foreign and domestic), food, services and tropical goods. She maximizes

$$
\mathrm{U}\left(\mathrm{C}_{M}, \mathrm{C}_{S}, \mathrm{C}_{\mathrm{A}^{\prime}}, \mathrm{C}_{T}\right)=\mathrm{C}_{\mathrm{M}}{ }^{\Theta M} \mathrm{C}_{S}{ }^{\Theta S} \mathrm{C}_{\mathrm{A}}{ }^{\Theta A} \mathrm{C}_{T}{ }^{\Theta T}
$$

subject to $\Sigma_{i} p_{i} C_{i}=Y$, where $M$ refers to a composite manufactured good. As is well known, Cobb-Douglas utility implies constant expenditure shares:

$$
\begin{aligned}
& c_{S}=\theta_{S} Y / p_{S} \\
& c_{A}=\theta_{A} Y / p_{A} \\
& c_{T}=\theta_{T} Y / p_{T}
\end{aligned}
$$

The utility function is, however, nested; at a lower level the consumer determines how much of the two manufactured goods (home and foreign) to consume, by solving

$$
\max \left[a_{A} c_{M A}^{s}+a_{F} c_{M F}^{s}\right]^{1 / s}
$$




$$
\text { s.t. } p_{M A} C_{M A}+p_{M F} C_{M F}=\theta_{M} Y
$$

which yields the following demand functions for manufactured goods:

$$
\begin{aligned}
& c_{M A}=\theta_{M}{ }_{P_{M A}}{ }^{t-1} / a_{A}{ }^{t}\left[\left(p_{M A} / a_{A}\right)^{t}+\left(p_{M F} / a_{F}\right)^{t}\right] \\
& c_{M F}=\theta_{M} P_{M F}{ }^{t-1} / a_{F}{ }^{t}\left[\left(p_{M A} / a_{A}\right)^{t}+\left(p_{M F} / a_{F}\right)^{t}\right]
\end{aligned}
$$

where $t=s /(s-1)$.

\section{Equilibrium}

Equilibrium is defined by the following conditions: for every sector, price equals cost; for every commodity, demand equals supply; and the consumer's income equals the rents on all endowments. If there are $\mathrm{n}$ sectors and $m$ commodities, this implies $n+m+1$ equations (and, owing to Walras' Law, $n+m$ independent equations), to solve for $n+m+1$ unknowns ( $n$ activity levels, $m$ prices and the consumer's income). Sectors here include those which transform goods into foreign exchange or vice versa, and that which transforms raw labor into agricultural and non-agricultural labor.

More concretely, there are 13 prices endogenously determined in terms of the numeraire (foreign exchange): $p_{M A}, p_{M F}, p_{A}, p_{T}, p_{Z}, p_{I}, p_{I E}, p_{S}, w_{R}, w_{A}, w_{N A}$, $r$, and $d$. There are 9 activity levels endogenously determined: $M_{A}, A, I, S$, $E_{A}, E_{I}, I_{T}, I_{M}$ and that associated with the migration sector. Finally, there is the income of the representative consumer to determine, making 23 endogenous variables in all.

The following equations are available to solve the model. First, there are the zero-profit equations for the four production sectors $[(13)-(16)]$. second, there is the zero-profit equation for the migration sector [(18)]. Third, there is the equation giving $p_{I E}$ in terms of $p_{I}[(21)]$. Fourth, there are the zero-profit conditions for the four trade sectors (three tradeable and foreign exchange): 


$$
\begin{gathered}
\mathrm{p}_{\mathrm{A}}=\mathrm{p}_{\mathrm{A}} \\
\mathrm{p}_{\mathrm{MF}}=\mathrm{p}_{M F} \\
\mathrm{p}_{\mathrm{T}}=\mathrm{p}_{\mathrm{T}} \\
1=\mathrm{K}_{\mathrm{P}_{\mathrm{IE}}} \mathrm{p}_{\mathrm{Z}}^{1-a}
\end{gathered}
$$

Fifth, there are the following statements that equate demand and supply

(letting $\underline{x}$ stand for the endowment of factor $\mathrm{X}$ ):

$$
\begin{gathered}
M_{A}=M_{A S}+C_{M A} \\
I=I_{M}+E_{I} \\
s=C_{S} \\
A=C_{A}+A_{M}+E_{A} \\
\underline{I}_{A}=I_{R} \\
L_{A}=I_{A A}+I_{A I} \\
L_{N A}=L_{M}+I_{S} \\
\underline{K}=K_{A}+K_{I}+K_{M}+K_{S} \\
\underline{R}=R_{A}+R_{I} \\
I_{M}=C_{M F} \\
I_{T}=C_{T}+T_{M}
\end{gathered}
$$

Finally, there is the equation defining the income of the consumer:

$$
Y=w_{R} \underline{\underline{I}}_{R}+r \underline{\underline{K}}+d \underline{R}+\underline{\underline{F}}
$$

where $\underline{F}$ is the consumer's endowment of the fixed factor.

There are thus these 22 equations, plus the full employment condition for the fixed factor $\mathrm{z}$, with which to solve for the 23 unknowns.

\section{The British model}

The British model is very similar to the Us model, but is considerably simpler. First, there are only three sectors: agriculture (Cobb-Douglas production), manufacturing and services (both C.E.s. production). Second, 
Britain is assumed to be 'small' in world markets for both food and manufactures; thus these prices are exogenous to the model, and there is no need to treat foreign demand for either good explicitly, as was the case for US cotton exports. Third, Britain exports manufactures and imports food (the opposite from the US case); food is assumed to be a homogenous good, and so domestic and foreign food do not substitute imperfectly in British consumption (as do domestic and foreign manufactures in US consumption). The British utility function is thus assumed to be a single-level Cobb-Douglas function, whereas the US utility function was a two-level nested function. 
Appendix Table 1.1

Estimated Factor Intensities: Share of Input costs in Gross output $\left(\theta_{i j}\right)$

\begin{tabular}{|c|c|c|c|c|c|c|c|}
\hline Industry & $\theta_{\mathrm{L}}$ & $\boldsymbol{\theta}_{\mathrm{K}}$ & $\theta_{R}$ & $\theta_{I}$ & $\theta_{A}$ & $\theta_{T}$ & $\boldsymbol{\theta}_{M}$ \\
\hline \multicolumn{8}{|c|}{ United States c. 1869} \\
\hline $\mathbf{M}$ & 0.401 & 0.437 & & 0.052 & 0.097 & 0.013 & \\
\hline A & 0.553 & 0.213 & 0.234 & & & & \\
\hline I & 0.684 & 0.230 & 0.086 & & & & \\
\hline s & 0.718 & 0.249 & & & & & 0.34 \\
\hline \multicolumn{8}{|c|}{ Great Britain c1871 } \\
\hline M & 0.510 & 0.240 & & 0.250 & & & \\
\hline A & 0.529 & 0.196 & 0.275 & & & & \\
\hline s & 0.491 & 0.505 & & & & & 0.004 \\
\hline
\end{tabular}

Source: See text for notation and O'Rourke and Williamson (1992) for sources. 
Appendix Table 1.2

Estimated National Accounts

\begin{tabular}{|c|c|c|c|c|c|c|c|c|c|}
\hline \multirow{2}{*}{ Industry } & \multirow{2}{*}{$\begin{array}{l}\text { Gross } \\
\text { Output }\end{array}$} & \multicolumn{7}{|c|}{ Input Costs } & \multirow{2}{*}{$\begin{array}{l}\text { Value } \\
\text { Added }\end{array}$} \\
\hline & & L & $\mathrm{K}$ & $\mathrm{R}$ & I & A & $\mathrm{T}$ & M & \\
\hline \multicolumn{10}{|c|}{ United States c. 1869 ( $\mathrm{(m.)}$} \\
\hline M & 2009.9 & 805.8 & 878.7 & & 104.5 & 194.5 & 26.4 & & 1684.5 \\
\hline A & 2457.2 & 1359.2 & 522.3 & 575.7 & & & & & 2457.2 \\
\hline I & 285.0 & 194.9 & 65.6 & 24.5 & & & & & 285.0 \\
\hline $\mathrm{S}$ & 2995.9 & 2149.7 & 745.5 & & & & & 100.7 & 2895.2 \\
\hline Total & 7748.0 & 4509.6 & 2212.1 & 600.2 & 104.5 & 194.5 & 26.4 & 100.7 & 7321.9 \\
\hline \multicolumn{10}{|c|}{ Britain c. 1871 (fm.) } \\
\hline M & 465.5 & 237.3 & 111.6 & & 116.6 & & & & 348.9 \\
\hline A & 130.4 & 69.0 & 25.6 & 35.8 & & & & & 130.4 \\
\hline$s$ & 399.2 & 196.2 & 201.6 & & & & & 1.4 & 397.8 \\
\hline Total & 995.1 & 502.5 & 338.8 & 35.8 & 116.6 & & & 1.4 & 877.1 \\
\hline
\end{tabular}

Source: See text for notation and $0^{\prime}$ Rourke and Williamson (1992) for sources. 
Appendix 2: Estimating the Contribution of Immigration and Emigration to the Labor Force in the United States and the United Kingdom, 1870-1910

In order to estimate the effect of international migrations on the labor force in the US and the UK 1870-1910, we work from the end year migrant stocks reported in censuses as residents born overseas. Using age/sex-specific labor participation rates, we then estimate what the labor force would have been had there been no international migration after 1870 . We prefer this approach to simply cumulating the migrant flows and subtracting or adding these to the change in the labor force over the period, since failure to allow for the death or retirement of migrants would lead to overestimates of the contribution of migration. Our approach also makes it possible to augment the estimates to include the impact of children born to migrants after the move.

\section{United States $1870-1910$}

One of the earliest attempts to make estimates of this sort was by Simon Kuznets (1952), and for the same period which interests us. Larry Neal and Paul Uselding (1972) greatly improved on Kuznets' method by using age-specific death rates to survive the native population backwards, and over a much longer period. We believe that our estimates are an improvement on both.

We start with the immigrant stock by sex and by eight different age groups from the 1910 US Census. We first estimate the proportion in each age/sex category who are likely to have immigrated before 1870 (based on the estimated age structure of the immigrants who arrived in the decade of the 1860s). These are deducted from the 1910 stock. We then apply age/sex-specific labor participation rates to the remainder, obtaining the total direct 
contribution of post-1870 immigration to the 1910 labor force.

The next step is to allow for the contribution of the children born in the US of post-1870 immigrants. To do so, we first take from the 1910 Census the numbers in each age/sex category whose parents were foreign-born plus half of those who were of mixed parentage. We then estimate the age of their parents by adding thirty years to each age group. Using the age structure of immigration (in the 1860s), we deduct the proportion of those children in each age/sex category whose parents are likely to have immigrated in 1870 or earlier. Finally, we apply age-specific labor participation rates to obtain the contribution of the children of post-1870 immigrants to the 1910 labor force.

A similar procedure was followed based on the 1890 Census to estimate the contribution of immigration since 1870 to the labor force in 1890 .

United Kingdom 1871-1911

We are unaware of any previous estimates for the United Kingdom. The procedure is not unlike that for the United States, except here we first need to identify the United Kingdom-born residing abroad, and second to apply United Kingdom labor participation and attitudes to family formation in a counterfactual world where they would have stayed home.

We first obtain the stock of UK emigrants by sex living in the US, Canada, Australia, New Zealand and South Africa. These were divided into the eight age groups: those in the US and Canada based on the age distribution of all US immgrants in 1910, and those in Australia, New Zealand and South Africa based on the age distribution of UK immigrants in Australia in 1911 . We then estimate the proportion in each age group who are likely to have emigrated 
1871 or before based on the age structure of immigration flows in the 1860 s. Deducting these from the 1911 stock abroad and applying age/sex-specific labor participation rates reported in England and Wales in 1911, we arrive at an estimate of the direct loss from the labor force of post-1871 emigration. We also need to estimate the reduction in the UK labor force due to the children that the post-1871 emigrants would have had had they remained in the UK. We begin by taking the ratios of each age/sex group in the UK in 1911 to the total population (male and female) thirty years older. We then apply these ratios to our estimated stock of post-1871 emigrants in 1911 to generate the number of children they would have had had they remained in the UK. Applying the 1911 labor participation rates to these numbers gives us our estimate of the effect of the loss of the emigrants' potential children to the UK labor force.

A similar procedure was followed based on the UK and overseas censuses for $1890 / 91$ to estimate the impact of UK emigration after 1871 on the labor force in 1891. 